\title{
Job satisfaction and associated factors among nurses in Bahir Dar city administrative, North West Ethiopia, 2017
}

\author{
Emiru Ayalew ${ }^{1 *}$ and Yinager Workineh ${ }^{2}$
}

\begin{abstract}
Objective: To assess the level of job satisfaction and associated factors among nurses in Bahir Dar city, Northwest Ethiopia, 2017.

Results: The overall proportion of nurses'job satisfaction was $43.6 \%$. From motivational factors, advancement $(A O R=2.64 ; 95 \% \mathrm{Cl}[1.17,5.96])$ and recognition $(\mathrm{AOR}=2.56 ; 95 \% \mathrm{Cl}[1.08,6.08])$ were the main determinants of nurses' job satisfaction. Among hygienic factors, work security (AOR $=4.88 ; 95 \% \mathrm{Cl}[1.13,21.03])$ was positively associated with nurses'job satisfaction. In conclusion, the nurses'job satisfaction was low in this study setting. Modifiable factors such as advancement, recognition and work security positively affect job satisfaction of nurses. Therefore, the current study recommended that the health care system administers should work on improvement of advancement, security, and recognition in the facilities.
\end{abstract}

Keywords: Job satisfaction, Hygienic, Motivational factors, Nurses

\section{Introduction}

Job satisfaction is a measure of cognitive and behavioral components of workers' comfort with their job [1,2]. It also refers to the outlook and spirits of professionals towards their work [3].

Physiological and psychological needs are the main factors of job satisfaction and dissatisfaction. Payment, supervision, fringe benefits, operating procedure, coworker and communication are physiological factors of job satisfaction. Similarly, the nature of work, promotion, and contingent are psychological factors. In addition to the above, work environment and supervision are hygienic factors of nurses' job satisfaction [4]. In general, the determinants of job satisfaction of professionals are classified as intrinsic and extrinsic factors [5].

Job dissatisfaction affects the quality and cost of patient care due to nurses' preservation from their tasks [6]. The dissatisfaction was higher in the hospital than other

\footnotetext{
*Correspondence: emiruayalew2010@gmail.com

${ }^{1}$ Department of Adult Health Nursing, College of Medicine and Health Science, Bahir Dar University, Bahir Dar, Ethiopia

Full list of author information is available at the end of the article
}

health facilities as evidenced by one in five nurses plan to depart their profession within a year [7].

The study conducted in Nigeria revealed that $67.1 \%$ of nurses are dissatisfied with their job [8]. A similar study done in Kampala, Uganda showed that $17.4 \%$ of nurses are satisfied [9]. Another study conducted in Malawi, Tanzania and South Africa stated 71\%, 82.3\%, and 52.1\% of nurses are satisfied respectively [10].

Different studies were conducted to investigate the determinants of nurses' job satisfaction. On this dimension, the study conducted in New Delhi showed that inadequate salary, lack of promotions, fringe benefits, training and rewards, poor working conditions, nature of work and coworkers were the main determinants of nurses' job satisfaction [11]. Another similar study conducted in Ethiopia indicated that hospital nurses are dissatisfied [6, 11].

A shortage of experienced nurses reduced the quality of care in the health facilities [12]. This critical and global problem of the health care system will be solved by augmenting the job satisfaction of nurses at the organization as well as individual levels.

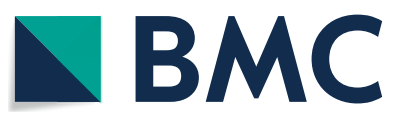

(c) The Author(s) 2019. This article is distributed under the terms of the Creative Commons Attribution 4.0 International License (http://creativecommons.org/licenses/by/4.0/), which permits unrestricted use, distribution, and reproduction in any medium, provided you give appropriate credit to the original author(s) and the source, provide a link to the Creative Commons license, and indicate if changes were made. The Creative Commons Public Domain Dedication waiver (http://creativecommons.org/ publicdomain/zero/1.0/) applies to the data made available in this article, unless otherwise stated. 
Even though nurses' job satisfaction is the base for quality health care, factors of dissatisfaction and leaving of their job weren't well investigated in Ethiopia before. Hence, the current study might add evidence for policymakers, health care administers and nurse managers to alleviate the barriers of job satisfaction in Ethiopia. Therefore, this study aimed to assess the level of nurses' job satisfaction and associated factors in Bahir Dar city, Northwest Ethiopia, 2017.

\section{Main text}

\section{Methods}

\section{Study design, setting and period}

The cross-sectional study design was conducted in Bahir Dar city public health facilities from 1 to 30 March 2017. Bahir Dar (capital city of Amhara region) is $565 \mathrm{~km}$ apart from Addis Ababa. In the city, there were two hospitals and ten health centers with a total of 441 nurses during the study.

\section{Sample size determination and procedure}

The sample size was determined by using a single population proportion formula. The following assumptions, such as a $95 \%$ confidence interval (CI), $5 \%$ the margin of error (d), $10 \%$ non-response rate and $52.5 \%$ of proportion (p) were considered [13].

$$
\begin{aligned}
& \mathrm{N}=\frac{(\mathrm{z} \alpha / 2)^{2} \times \mathrm{p}(1-\mathrm{p})}{\mathrm{d}^{2}} \\
& \mathrm{~N}=\frac{(1.96)^{2} \times 0.525(1-0.525)}{(0.05)^{2}}=383.1996 \sim 383 .
\end{aligned}
$$

Finally, by using the correction formula and $10 \%$ nonresponse rate, the sample size was 226 .

Two hospitals and ten health centers were selected from Bahir Dar city. Lists of nurses were obtained from each facility payroll. The sample sizes were proportionally allocated in each health institution based on the number of nurses. Then, the study participants were selected by simple random sampling methods. The nurses in annual, learning and maternity leave were excluded from the study.

\section{Measurement tool}

A structured self-administered questionnaire was used to collect the data. The authors measured the outcome variables based on Job satisfaction scale and Minnesota Questionnaire [12, 14]. Negative items were reversed to positive before summing. The measuring items on nurses' job satisfaction were achievement, advancement, work itself, recognition, growth at work, organization policy, relationship with colleague and supervisor, payment and working condition. We calculated the scores of each factor based on the answers to all items. Finally, nurses' job satisfaction was determined by using the demarcation threshold formula [15].

\section{Data processing and analysis}

We coded, entered, cleaned and analyzed the data using SPSS version 21 . The frequency of each variable was calculated. The logistic regression model was used to determine statistical significance of variables. In this model, the odds ratio with $95 \%$ confidence interval was used to determine the strength of association between dependent and independent variables. The variables with a p-value of less or equal to 0.2 in bivariate analysis model were transferred to multivariate. Finally, we considered the p-values less than 0.05 as statistically significant.

\section{Results}

\section{Demographic profiles of respondents}

Among 226 sampled nurses, 220 of them have participated with the response rate of $98.3 \%$. In the current study, 106 (48.2\%) and 133 (60.5\%) nurses were females and married respectively. The mean age of participants was 30.05 ( $\mathrm{SD}= \pm 6.172$ ) years. Regarding educational status, $121(55 \%)$ nurses were BSc holders. Fifty-six $(25.5 \%)$ nurses had ten or more years of work experience (Table 1).

\section{Nurses agreement with motivational and hygienic factors of job satisfaction}

In this study, $27.7 \%$ of nurses reported that payment is hygienic factors of job satisfaction. Similarly, $79.5 \%$ of nurses stated that relationship with friends as hygienic factors. On the other hand, $69.1 \%$ and $68.6 \%$ of nurses disagreed on working conditions and work security respectively as hygienic factors of job satisfaction. In the current study, the overall job satisfaction was $43.6 \%$ (Table 2).

\section{Factors associated with job satisfaction}

In this study, multivariate logistic regression analysis indicated that advancement, work security and recognition were the main determinants of nurses' job satisfaction. 
Table 1 Socio-demographic characteristics of study participant at Bahir Dar, North west Ethiopia, June 2017

\begin{tabular}{|c|c|c|c|}
\hline Variable & Category & Frequency & Percent \\
\hline \multirow[t]{2}{*}{ Sex } & Male & 114 & 51.8 \\
\hline & Female & 106 & 48.2 \\
\hline \multirow[t]{4}{*}{ Current age in year } & $20-30$ & 142 & 64.5 \\
\hline & $31-40$ & 64 & 29.1 \\
\hline & $41-50$ & 13 & 5.9 \\
\hline & $\geq 51$ & 1 & 0.5 \\
\hline \multirow[t]{4}{*}{ Marital status } & Single & 59 & 26.8 \\
\hline & Married & 133 & 60.5 \\
\hline & Divorced & 15 & 6.8 \\
\hline & Widowed & 13 & 5.9 \\
\hline \multirow[t]{4}{*}{ Religion } & Orthodox Tewahido & 126 & 57.3 \\
\hline & Protestant & 37 & 16.8 \\
\hline & Muslim & 28 & 12.7 \\
\hline & Other & 29 & 13.2 \\
\hline \multirow[t]{3}{*}{ Ethnicity } & Amhara & 189 & 85.9 \\
\hline & Oromo & 14 & 6.4 \\
\hline & Other & 17 & 7.7 \\
\hline \multirow[t]{3}{*}{ Educational status } & Diploma nurse & 95 & 43.2 \\
\hline & BSc. nurse & 121 & 55 \\
\hline & MSc. & 4 & 1.8 \\
\hline \multirow[t]{5}{*}{ Work experience } & 6 month to $<1$ year & 53 & 24.1 \\
\hline & 1 year to $<2$ years & 29 & 13.2 \\
\hline & 2 years to $<5$ years & 35 & 15.9 \\
\hline & 5 years to $<10$ years & 47 & 21.4 \\
\hline & $\geq 10$ years & 56 & 25.5 \\
\hline \multirow[t]{2}{*}{ Institution } & Hospital & 138 & 62.3 \\
\hline & Health center & 62 & 37.7 \\
\hline
\end{tabular}

Table 2 Frequency distribution of nurses' agreement with motivational and hygienic factors in Bahir Dar administrative city, 2017

\begin{tabular}{lll}
\hline Variables & \multicolumn{2}{l}{ Level of agreement in percent } \\
\cline { 2 - 3 } & Agreement (\%) & $\begin{array}{l}\text { Disagreement } \\
\text { (\%) }\end{array}$ \\
\hline Achievement & 64.5 & 34.5 \\
Advancement & 59.5 & 40.5 \\
Work it self & 75 & 25 \\
Recognition & 55.5 & 44.5 \\
Growth at work & 70 & 30 \\
Organization policy & 49.1 & 50.9 \\
Work security & 32.4 & 68.6 \\
Relationship with friends & 79.5 & 20.5 \\
Relationship with supervisors & 42.3 & 57.7 \\
Payment & 27.7 & 72.3 \\
Working condition & 30.9 & 69.1 \\
\hline
\end{tabular}

From all motivating factors, advancement $(\mathrm{AOR}=2.64$; $95 \% \mathrm{CI}[1.17,5.96])$ and recognition $(\mathrm{AOR}=2.56$; $95 \% \mathrm{CI}$ $[1.08,6.08])$ were positively associated with job satisfaction of nurses as compared with its counterparts. Among hygiene factors, work security $(\mathrm{AOR}=4.88$; 95\% CI $[1.13$, 21.03]) was the only determinants of nurses' job satisfaction (Table 3).

\section{Discussion}

The determination of job satisfaction and associated factors among nurses in Bahir Dar, North West Ethiopia was the main objective of the current study. Based on this aim, the job satisfaction of nurses was $43.6 \%$. This finding is similar to studies done in Turkey, Pakistan, and Ethiopia [15-17]. On the other corner, it is higher than studies conducted in Nigeria (32.9\%) and Uganda (17.4\%) $[8,9]$, but lower than the study done in, Malawi (71.0\%), Tanzania (82.6\%), South Africa (52.1\%) and Sidama $(52.5 \%)$ [10, 13]. The possible reasons for this difference might be due to variation in the study setting, educational level, measuring tools and salary between the current and previous studies.

In this study, the determinants of nurses' job satisfaction were assessed. The result pointed out that the advancement was the positive risk factors of nurses' job satisfaction. This is in line with the study done in England [5]. The high level of job satisfaction in advancement might be due to the nurses' perception of gradual improvement or development.

Similarly, the current study revealed that recognition as a motivational factor had a positive association with job satisfaction of nurses. The finding agrees with studies conducted in England, India, Pakistan, and Ethiopia $[5,15,16,18]$. Hence, constructive recognition should be given to promote job satisfaction of employees.

Work security was the last but not the least factor of nurses' job satisfaction. In this case, work security positively promoted the satisfaction of nurses. This is in agreement with the studies carried out in China, Turkey, and Ethiopia [1, 17, 19]. The high level of job satisfaction in work security might be due to its positive effect on physical and psychological comforts of nurses.

\section{Conclusion}

The nurses' job satisfaction was low in this study setting. Modifiable factors such as advancement, recognition and work security increased job satisfaction of nurses. Therefore, the current study recommended that the health care system administers should work on 
Table 3 Results from Bivariate and multiple logistic regression analysis about nursing satisfaction in Bahir Dar administrative city, June 2016

\begin{tabular}{|c|c|c|c|c|c|}
\hline \multirow[t]{3}{*}{ Variables } & \multirow[t]{3}{*}{ Categories } & \multicolumn{2}{|c|}{ Level of satisfaction } & \multicolumn{2}{|c|}{ Odds ratio ( $95 \%$ confidence interval) } \\
\hline & & Satisfied & Not satisfied & COR $(95 \% \mathrm{Cl})$ & AOR $(95 \% \mathrm{Cl})$ \\
\hline & & $N(\%)$ & $N(\%)$ & & \\
\hline \multirow[t]{5}{*}{ Work experience } & 6 month-1 year & $19(35.8)$ & $34(64.2)$ & 1.00 & 1.00 \\
\hline & $1-2$ year & $10(34.5)$ & $19(65.5)$ & $0.94(0.36,2.43)$ & $0.82(0.23,2.96)$ \\
\hline & $2-5$ year & $17(51.4)$ & $18(48.6)$ & $1.69(0.71,4.03)$ & $0.68(0.19,2.43)$ \\
\hline & $5-10$ year & $26(55.3)$ & $21(44.7)$ & $2.216(0.99,4.95)$ & $1.51(0.49,4.63)$ \\
\hline & $\geq 10$ year & $24(42.9)$ & $32(57.1)$ & $1.342(0.620,2.903)$ & $0.73(0.24,2.22)$ \\
\hline \multirow[t]{2}{*}{ Achievement } & Agree & $81(57)$ & $61(43)$ & $5.56(2.90,10.73)^{*}$ & $2.21(0.86,5.64)$ \\
\hline & Disagree & $15(19.2)$ & $63(80.8)$ & 1.00 & 1.00 \\
\hline \multirow[t]{2}{*}{ Advancement } & Agree & $61(68.5)$ & $28(31.5)$ & $5.98(3.31,10.79)^{*}$ & $2.64(1.17,5.96)^{*}$ \\
\hline & Disagree & $35(26.7)$ & $96(73.3)$ & 1.00 & 1.00 \\
\hline \multirow[t]{2}{*}{ Work itself } & Agree & $87(52.7)$ & $78(47.3)$ & $5.70(2.62,12.39)^{*}$ & $1.60(0.55,4.66)$ \\
\hline & Disagree & $9(16.4)$ & $46(83.6)$ & 1.00 & 1.00 \\
\hline \multirow[t]{2}{*}{ Growth at work } & Agree & $82(53.2)$ & $72(46.4)$ & $4.23(2.17,8.26)^{*}$ & $1.63(0.65,4.09)$ \\
\hline & Disagree & $14(21.2)$ & $52(78.8)$ & 1.00 & 1.00 \\
\hline \multirow[t]{2}{*}{ Recognition at work } & Agree & $78(63.9)$ & $44(36.1)$ & $7.88(4.19,14.81)^{*}$ & $2.56(1.08,6.08)^{*}$ \\
\hline & Disagree & $18(18.4)$ & $80(80.6)$ & 1.00 & 1.00 \\
\hline \multirow[t]{2}{*}{ Organization policy } & Agree & $71(65.7)$ & $37(34.3)$ & $6.68(3.68,12.13)^{*}$ & $1.63(0.64,4.14)$ \\
\hline & Disagree & $25(22.3)$ & $87(77.7)$ & 1.00 & 1.00 \\
\hline \multirow[t]{2}{*}{ Relationship with friends } & Agree & $88(50.3)$ & $87(49.3)$ & $4.68(2.06,10.62)^{*}$ & $0.99(0.32,3.09)$ \\
\hline & Disagree & $8(17.8)$ & $37(82.2)$ & 1.00 & 1.00 \\
\hline \multirow[t]{2}{*}{ Work security } & Agree & $60(87)$ & $9(13)$ & $21.26(9.62,47.13)^{*}$ & $4.88(1.13,21.03)^{*}$ \\
\hline & Disagree & $36(23.8)$ & $115(76.2)$ & 1.00 & 1.00 \\
\hline \multirow[t]{2}{*}{ Payment } & Agree & $51(83.6)$ & $10(16.4)$ & $12.92(6.04,27.64)^{*}$ & $2.64(0.73,9.62)$ \\
\hline & Disagree & $45(28.3)$ & $114(71.7)$ & 1.00 & 1.00 \\
\hline \multirow[t]{2}{*}{ Relationship with supervisor } & Agree & $61(65.6)$ & $32(34.4)$ & $5.01(2.81,8.94)^{*}$ & $1.85(0.82,4.17)$ \\
\hline & Disagree & $35(27.6)$ & $92(72.4)$ & 1.00 & 1.00 \\
\hline \multirow[t]{2}{*}{ Working condition } & Agree & $56(82.4)$ & $12(17.6)$ & $13.07(6.36,26.86)^{*}$ & $0.63(0.14,2.85)$ \\
\hline & Disagree & $40(26.3)$ & $112(73.7)$ & 1.00 & 1.00 \\
\hline
\end{tabular}

Italicized-significantly associated value

*Statistically significant $p<0.05$

improvement of advancement, security, and recognition in the facilities.

\section{Limitations}

Since this study assessed motivation and satisfaction related issues, it might bring emotional responses. Application of cross-sectional study could not detect the cause-effect relationship between the variables.

\section{Abbreviations \\ AOR: adjusted odds ratio; Cl: confidence interval; COR: crowd odd ratio; SPSS: statistical.}

\section{Acknowledgements}

The authors would like to thank Bahir Dar University, college of medicine and health sciences for financial and facilities support of the study. The authors are also grateful to nurses who participated in the study. The last but not the least we would like to thank the head of each selected health institutions for their cooperation in undertaking research endeavors.

\section{Authors' contributions}

$E A$ is the primary investigator responsible for the overall conceptualization and designing of the research project. EA and YW analyzed, interpreted, and wrote the result, and also revised the manuscript. Both authors read and approved the final manuscript.

\section{Funding}

Not applicable.

\section{Availability of data and materials}

The data of this study can't be shared publicly due to presence of sensitive (confidential) participants' information.

Ethics approval and consent to participate

Ethical clearance was obtained from the Research Ethical Review Committee of Bahir Dar University. Permission and supporting letters were taken from 
respective office before data collection. Written consent was also obtained from all respondents.

\section{Consent for publication}

Not applicable.

\section{Competing interests}

The authors declare that they have no competing interests.

\section{Author details}

${ }^{1}$ Department of Adult Health Nursing, College of Medicine and Health Science, Bahir Dar University, Bahir Dar, Ethiopia. ${ }^{2}$ Department of Child Health Nursing, College of Medicine and Health Science, Bahir Dar University, Bahir Dar, Ethiopia.

Received: 4 December 2018 Accepted: 5 June 2019

Published online: 07 June 2019

\section{References}

1. Onuoha P, Stephen A, Bernard P, Corban A, Mahabir M, Israel-Richardson D. Factors that contribute to work motivation and job satisfaction among hospital nurses in Trinidad and Tobago. Int J Health Sci Res. 2017;7(1):208-17.

2. Hulin $\mathrm{CL}$, Judge TA. Job attitudes. Handbook of psychology: industrial and organizational psychology, vol. 12. Wiley: New York; 2003. p. 255-76.

3. Aziri B. Job satisfaction: a literature review. Manag Res Pract. 2011;3(4):77-86.

4. Rosales RA, Labrague $L$, Rosales GL. Nurses'job satisfaction and Burnout: is there a connection? Int J Adv Nurs Stud. 2013;2(1):1.

5. Lephalala R, Ehlers VJ, Oosthuizen MJ. Factors influencing nurses' job satisfaction in selected private hospitals in England. Curationis. 2008;31(3):60-9

6. Gulavani A, Shinde M. Occupational stress and job satisfaction among nurses. Int J Sci Res (IJSR). 2014;3(4):733-40.

7. Berhe H. Job satisfaction of nurses and associated factors in public hospitals in Tigray Region, Northern Ethiopia. Greener J Med Sci. 2014:4(1):022-37.

8. Ayamolowo SJ. Job satisfaction and work environment of primary health care nurses in Ekiti State, Nigeria: an exploratory study. Int J Caring Sci. 2013;6(3):531.
9. Nabirye RC, Brown KC, Pryor ER, Maples EH. Occupational stress, job satisfaction and job performance among hospital nurses in Kampala, Uganda. J Nurs Manag. 2011;19(6):760-8.

10. Blaauw D, Ditlopo P, Maseko F, Chirwa M, Mwisongo A, Bidwell P, Thomas $\mathrm{S}$, Normand C. Comparing the job satisfaction and intention to leave of different categories of health workers in Tanzania, Malawi, and South Africa. Glob Health Action. 2013;6(1):19287.

11. Kohli S, Bagga R. Job satisfaction amongst contractual and regular nursing staff in two government hospitals of Delhi: a comparison. Health Popul Perspect Issues. 2013;36:98-107.

12. Baylor KM. The influence of intrinsic and extrinsic job satisfaction factors and affective commitment on the intention to quit for occupations characterized by high voluntary attrition; 2010.

13. Asegid A, Belachew T, Yimam E. Factors influencing job satisfaction and anticipated turnover among nurses in Sidama zone public health facilities, South Ethiopia. Nurs Res Pract. 2014. https://doi. org/10.1155/2014/909768.

14. Weiss DJ, Dawis RV, England GW. Manual for the Minnesota satisfaction questionnaire. Minnesota studies in vocational rehabilitation. Minneapolis: University of Minnesota; 1967.

15. Yami A, Hamza L, Hassen A, Jira C, Sudhakar M. Job satisfaction and its determinants among health workers in Jimma university specialized hospital, southwest Ethiopia. Ethiop J Health Sci. 2011;21(3):19-27.

16. Kumar R, Ahmed J, Shaikh BT, Hafeez R, Hafeez A. Job satisfaction among public health professionals working in public sector: a cross sectional study from Pakistan. Hum Resour Health. 2013;11(1):2.

17. Masum AKM, Azad MAK, Hoque KE, Beh L-S, Wanke P, Arslan Ö. Job satisfaction and intention to quit: an empirical analysis of nurses in Turkey. PeerJ. 2016:4:e1896

18. Ali N, Ali A. The mediating effect of job satisfaction between psychological capital and job burnout of Pakistani nurses. Pak J Commer Soc Sci. 2014;8(2):399.

19. Bekru ET, Cherie A, Anjulo AA. Job satisfaction and determinant factors among midwives working at health facilities in Addis Ababa city, Ethiopia. PLOS ONE. 2017;12(2):e0172397.

\section{Publisher's Note}

Springer Nature remains neutral with regard to jurisdictional claims in published maps and institutional affiliations.
Ready to submit your research? Choose BMC and benefit from:

- fast, convenient online submission

- thorough peer review by experienced researchers in your field

- rapid publication on acceptance

- support for research data, including large and complex data types

- gold Open Access which fosters wider collaboration and increased citations

- maximum visibility for your research: over $100 \mathrm{M}$ website views per year

At BMC, research is always in progress.

Learn more biomedcentral.com/submissions 